\title{
Italian youth mobility during the last two decades: an overview in eight selected EU countries
}

\author{
GERARdo GALLO ${ }^{1}$ and BARbara STANISCIA ${ }^{2}$
}

\begin{abstract}
The international mobility of young people from Europe's Mediterranean countries has become an important topic in scientific debate. The issue has major reverberations in the national media since youth outflows - not adequately compensated for by return flows or new inflows - can undermine the economic and social sustainability of development processes in the countries of origin. The 2007-2008 financial and economic crisis, contributed significantly to intensifying those outflows and reducing the return flows. This paper focuses on the international mobility of young Italians during the past two decades. After addressing the problem of existing data sources and their comparability, our analysis, in terms of spatial distribution, will be concentrated on eight EU destination countries presenting three different sets of socio-economic characteristics: the UK, Germany and Sweden (characterised by high mobility, high income, and high capacity for attracting immigration); Latvia, Romania and Slovakia (characterised by high out mobility, medium-low income, and low capacity for attracting immigration) and Ireland and Spain (characterised by high mobility, mediumhigh income, and a temporally and spatially discontinuous capacity for attracting immigration). In terms of geographical distribution, our analysis will consider the most represented places of origin in Italy at the provincial level. Our study provides an overview of international outflows of young Italians, considering destination countries, places of origin, gender, marital status and age. These results could be used by scientists and policymakers in dealing with the challenge of maximizing the advantages of mobility for individuals while minimizing costs in terms of social and economic sustainability.
\end{abstract}

Keywords: youth mobility, intra-EU mobility, Italy, regional disparities, economic crisis

\section{Introduction}

Starting in the $21^{\text {st }}$ century, the international mobility of young people has been a major focus of attention in the international literature. Early on, this was particularly the studies concerning the international mobility of students and researchers and of highly skilled workers. A comprehensive analysis and literature review on the topic is provided by KING, R. et al. (2016a) working from various questions regarding youth mobility: Who migrates? Where do young people migrate to? Why and how do they migrate? The authors look into the effects of youth mobility on the regions of origin and those of the destination, and the effects at the personal and individual level, both objective and subjective, of the migration experience.

Youth mobility within the EU has become an issue of major importance and relevance in the countries of Mediterranean Europe. Starting with the economic and financial crisis that began in 2007-2008, the phenomenon has captured the attention of the media, of policy-makers and of the public because of the feared negative repercussions both for young people - "forced" to flee the Mediterranean area because of the high unemployment rates and the structural crisis and for the regions where the flows originate, "condemned" to increased marginalization as a result of the loss of human capital (AlbAMonteserín, S. et al. 2013; LAbrianidis, L. and

${ }^{1}$ ISTAT - Italian National Institute of Statistics, Rome.

${ }^{2}$ Sapienza University of Rome. Corresponding author's e-mail: barbara.staniscia@uniroma1.it 
Vogiatzis, N. 2013; Domingo, A. et al. 2014; Triandafyllidou, A. and Gropas, R. 2014; Díaz-Hernández, R. et al. 2015; Pumares, P. 2015; Domínguez-Mujica, J. and PérezGarcía, T. forthcoming).

Youth mobility and its increase after the 2007-2008 economic crisis, unites Mediterranean and Eastern European countries (EEC), even with different intensities. Italy has one of the lowest fertility rates in the EU, with a negative trend between the year 1970 (2.38) and the year 2000 (1.26). In 2000, the only EEC showing a lower rate was Czech Republic (1.15), even if other EEC did not display very high values (ex. Bulgaria: 1.26; Romania: 1.31; Hungary: 1.32) (EUROSTAT, 2016a). Thus, the increase in youth mobility cannot be linked to an increase of the youth cohors of the population. Unlike EEC, Italy did not experience a change in the possibility of increased mobility for youth after 1989, as much as their mobility was not affected by the existence of the Schengen Agreement (Italy signed the treaty in 1990). Thus, the increase of youth mobility in Italy cannot be attributed to radical changes in the global political arena, except for EU policies, as will be discussed below.

The European Commission - beginning with the Lisbon Treaty and reconfirmed in the Europe 2020 strategy - encourages the mobility of young people through various policies, programmes and initiatives. Some aim to encourage the mobility of students (Bologna Process, ERASMUS and SOCRATES programmes), while others facilitate the mobility of researchers (ERA-European Research Area), and still others are intended to encourage labour mobility (Youth on the Move, Youth Employment Package, Youth Guarantee). This push toward international mobility on the part of the Commission leads to the creation (or worsening) of problems in places of origin, which suffer a "haemorrhaging" of the potential energy of young people, especially those with high levels of education and qualifications. There seem to be, thus, two (currently opposing) interests with regard to the Commission's overall policy: to encourage the mobility of young people to create a European labour market and identity on the one hand, while on the other hand, avoiding the marginalization of certain areas and promoting regional re-equilibrium.

There are two other interests that are currently in conflict: one individual and the other at the community level. There is, on the one hand, young people's interest in promoting their own personal growth, improving their quality of life and developing their portfolio of skills, competencies and experiences through international mobility. By the same token, this is a salient interest among the communities of origin in retaining their main sources of "renewable energy". This conflict centres attention on the impact of mobility in terms of the supply of human capital, in the regions of origin and in the destination: what effects are generated by this "brain mobility" that youth mobility has set in motion? Are we looking at new forms of brain drain, brain waste, brain training, brain overflow or brain circulation (LoweLL, B.L. and Findlay, A. 2002)? In theory, the regions of origin benefit from brain mobility if there is brain circulation or brain return. Otherwise, the free movement of persons undermines the cohesion policy launched in 1988 with the aim of integrating the existing European funds for regional development (EAGGF, EDRF, ESF) to reduce inequality in Europe. It was intended to promote growth in less-developed regions and in disadvantaged communities in isolated areas of the EU with implicitly assumed very low geographical mobility (Jouen, M. 2014). The contradictions between the policies of cohesion and of mobility are persistent and fundamental to the future vision of youth mobility.

In Italian scientific debate, scholars have, in recent years, focused on the upswing in migration - both internal and international - as a result of the system-wide crisis. The flows from the south to the centre-north of Italy and to other countries have been emphasized and viewed with concern (BonifAzI, C. 2015; GiannolA, A. 2015; SVIMEZ 2015). An increase is observed in the level of education 
of those skilled and highly skilled migrants who move and are willing to accept jobs for which they are overqualified. In geographical terms, some studies have highlighted the "rediscovery" of older destinations which had, for several decades, disappeared from migrants' "mental maps" (e.g. Argentina), and the continuing importance of the highly attractive European countries (e.g. Germany, the UK, France) (Pugliese, E. 2015).

In analysing young Italians in London, McKay, S. (2015) points out that the number of young people from the Mediterranean has been on the rise since the 2007 crisis. More young Italians moved to the UK from 2007 to 2011 than in the thirty years from 1961 to 1991; in 2012 the number of Italians who moved to the UK exceeded the number from any other country in Southern Europe (Spain, Portugal, Greece). The flow towards Germany also regained momentum beginning in 2010 and, in 2013, inflows from Italy were the highest of those from any Mediterranean country. A high percentage of Italians moving to Germany (especially women) were under the age of 25 (HAUG, S. 2015).

KING, R. et al. (2016b), in their analysis of new flows of young people - Germans, Italians and Latvians - in London, draw attention to characteristics including: (i) the renewed importance of the contrast between developed and less-developed economies in the world and in Europe, (ii) the attractiveness of London as a Eurocity (FAVELL, A. 2008) and a global city (SASSEN, S. 2001), and (iii) the economic crisis. Italy itself is divided in two, a "developed" North and a "less developed" South.

In this paper we analyse the mobility of Italian young people (aged 15 to 34 years old), during the last two decades (1995-2014), toward eight countries in the European Union characterized by different profiles in terms of attractiveness to migrants: the UK, Germany and Sweden (characterized by high mobility, high income, and high capacity for attracting immigration); Latvia, Romania and Slovakia (characterized by high out- bound mobility, medium-low income, and low capacity for attracting immigration) and Ireland and Spain (characterized by high mobility, medium-high income, and a temporally and spatially discontinuous capacity for attracting immigrants). The analysis focuses on the sizes of the flows, on the differences in gender and location of origin between the young and the very young (analysis by area will be carried out at the level of provinces).

Through data analysis at the provincial level we intend to test the hypothesis that the recent international mobility of young Italians is induced, mostly, by economic factors. We intend to explore the possibility that it is motivated by the desire of young people to experiment with new lifestyles, of enriching language capacity, expanding cultural background, and improving skills and competencies. In this case, mobility will presumably not follow the classical path of labour migration characterized by permanent settlement and non-return. We intend, also, to verify if southern Italy still represents the main area of out-migration, if it is an homogeneous area, and if there are spatial differences in the south.

\section{Definitions, sources, data}

Prior to analysing of the data, a careful description and discussion of operational choices is provided, i.e., definitions adopted, data selected, and indicators chosen for analysing the recent dynamics of Italian emigration to the eight countries described previously.

\section{Definitions of emigrants and critical issues in the use of administrative data}

In terms of defining the emigration events examined, it should be specified that, both at the macro and micro levels, the basic data used refer to the transfer of residence abroad by persons who are registered with each Italian municipality's Population Register Offices. The population register regulation (Law 
no. 223 of 30 May 1989) requires all citizens (Italian and foreign) who reside in Italy to inform the Register Office in their municipality of changes in their place of usual residence if their stay outside Italy lasts for at least one year. This rule is also explicitly provided for international law, by (EC) Regulation No. $862 / 2007$ of the European Parliament and the Council of Europe of 11 July 2007, which governs migration statistics of EU member states. In particular, according to the international definition "Emigrants are people leaving the country where they usually reside and effectively taking up residence in another country. According to the 1998 UN recommendations on international migration statistics (Revision 1), an individual is a long-term emigrant if he/she leaves his/her country of previous usual residence for a period of 12 months or more" (UNECE 1998). However, it should be noted that this principle of mandatory reporting is not always respected in reality, and that the data from the population registers in almost every country in Europe are often forced to deal with the problem of citizens who emigrate without reporting their departure.

Wallgren, A. and Wallgren, B. (2011) and Poulain, M. and Herm, A. (2013) pointed out that the use of the population register to count the usual resident population does not automatically solve reporting problems: the accuracy of this register is a critical issue. Administrative data on a population involve problems in reporting due mainly to the difficulty in recording international migration which primarily concerns two main subpopulations: citizens or foreigners habitually living abroad who have official residence in the country and usually-resident foreigners without legal residence in the country. In Italy, nationals living abroad and foreigners who have left the country permanently or on a long-term basis should be removed from the population registers. However, emigrants see no reason to notify the authorities of their departure. In addition, local authorities have an incentive to maintain the stability of their population numbers by considering these people "temporary" emigrants, so they keep them in the registers (Cibella, N. et al. 2015). ${ }^{3}$

Despite the extent of under-reporting of migrations, the data from population registers are still a valuable source of information for analyzing the demographic characteristics, destination countries and regions of origin of individuals who have moved abroad.

\section{Data and indicators}

In the first part of the work, data used to analyse the evolution of the national mobility of Italian citizens abroad during the past two decades were taken from the names entered in and cancelled from population registers for Italian citizens who transferred their place of residence abroad from 1995 to 2014. For this period, the trends and the size of the flows, the main demographic characteristics and the destination countries are analysed.

In the second part of the paper, we examine in detail the provinces of origin from transfers of residence. Data are analysed by comparing two points in time: the first threeyear period of the new millennium (20022004) and the most recent three-year period for which data are available (2011-2013).

Individual data validated by the Italian National Institute of Statistics (ISTAT) make it possible to calculate indicators that express people's propensity toward international migration, across all of Italy's provinces, as well as providing information about gender, age, marital status and destination country of those who moved. In particular, reference is made to the specific migration rates which have been calculated by gender and also for the younger age groups (15-34 years), and by the ratio of the number of emigrants who registered their departure abroad in a given year and the average of usual resident population in their area of origin. This ratio has been broken down by gender and age group

\footnotetext{
${ }^{3}$ It should be noted that neither ISTAT or EUROSTAT provide estimates of individuals who permanently moved abroad without notifying the local authorities of their departure.
} 
so as to allow for the precise construction of specific rates, as well as according to the classification and division into macro areas of destinations. The construction of emigration rates makes it possible to create maps focusing on specific periods of time and very fine geographical scale.

Moreover, ISTAT carried out an initial trial to identify the usual resident population by using administrative data for defining the new census strategy. ISTAT analysed the quality of the registers and identified patterns in the administrative data. These patterns enabled ISTAT to classify individuals into specific groups, which also represent the "critical" subpopulations to be considered when evaluating population register data. Data used in the trial came from specific administrative sources already stored and integrated in the System of Microdata (SIM): Municipal Resident Population, Residence Permits, Employees and Self-employed persons, Compulsory Education, University Students, Retired People, Non-Pension Benefits, Income and Taxation.

The most important subpopulation that emerged from the aforementioned assessment is represented by individuals present in the population registers without "indications" from other administrative sources. The absence of "indications" in the labour and education registers could involve a high risk of emigration, especially for younger people (Chieppa, A. et al. 2016). For this reason, our analysis also considers the provincial indicator of young Italians who are listed in the population register but for whom the available administrative sources offer no direct indication of study and work, nor even indirect indications, such as declarations of dependent family members of an incomeearning parent.

\section{Results}

The early 1990s saw a radical change in the dynamics of Italy's resident population. Population growth began to be almost exclusive- ly the result of the significant and continuous arrival of foreign nationals from abroad.

The sudden slowdown in flows of Italians going abroad, which had begun in the mid1970 s and also simultaneously led to the recording of significant return flows, seemed to have made migration to other countries decisively stagnant. However, with the increase of migrants coming from the other European Union member countries, which since 1995 has risen from less than one million to more than 3.3 million people (Livi BACCI, M. 2016), Italian emigration has made its contribution, although mostly in recent years and as a result of particular conditions.

An overall picture of Italians' moving abroad and their demographic characteristics

Italian citizens' net migration to and from foreign countries was almost null in the 1995-1998 period and hit a slightly more negative low point only for $1999(-24,000$ persons). At the beginning of the new millennium, and until the end of 2010, the balance of Italians abroad alternated somewhat between positive and negative, but was in any case very small; then, suddenly, it exceeded 50,000 persons in 2013 (Figure 1).

Several scholars are beginning to discuss the "new European mobility" which, encouraged by the economic and financial crisis that spread through Europe starting in 2007-2008 and by the stronger process of integration of the European Union (EU) -, in fact seems to be affected by new conditions of need. As in the past, it has also been true in recent years that one of the important factors that encourage new processes of mobility by Italians, especially the young, is that of social networks that today have new communication tools at their disposal in the form of blogs and other forums on social networks (PICHLER, E. 2015).

On the whole, from the mid-1990s to the end of 2013, about 900,000 Italians left Italy (Table 1). The flows that involved EU countries account for just under 500,000 and more than half of those $(273,000)$ chose 


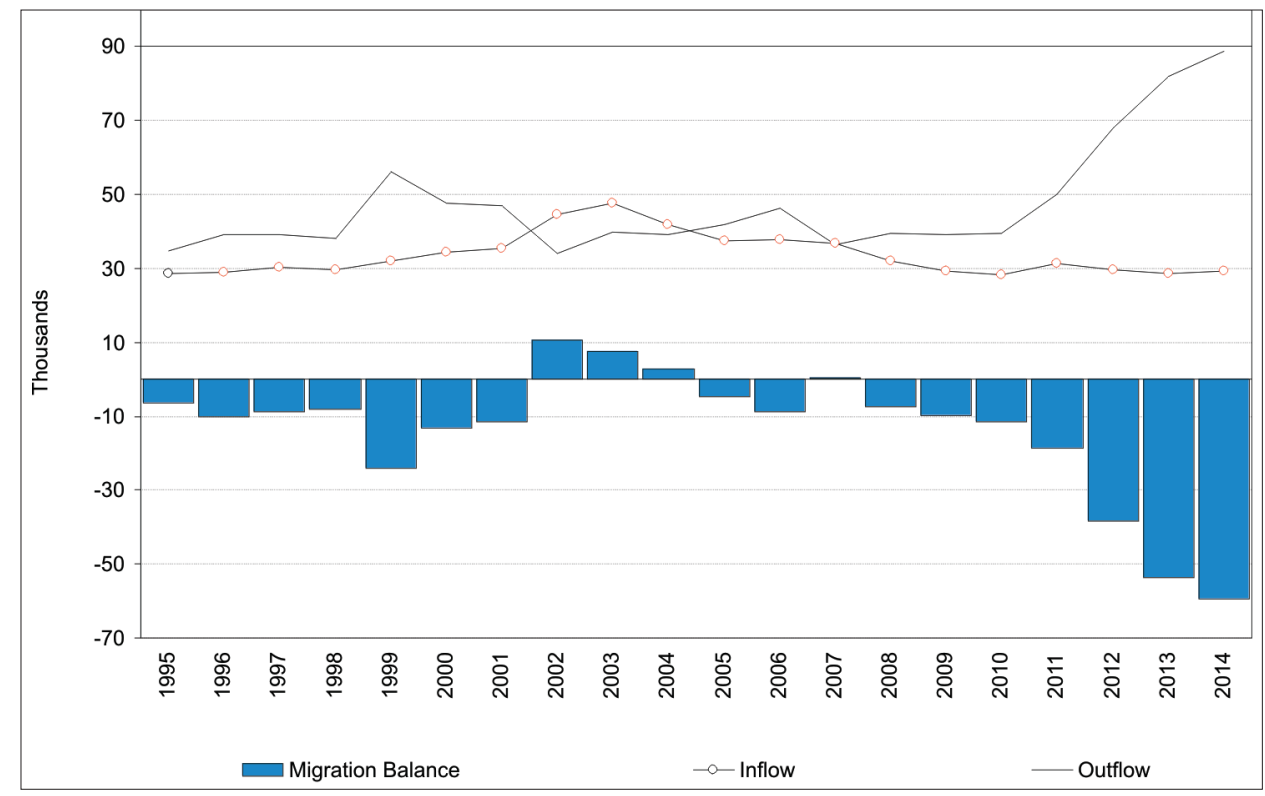

Fig. 1. In-flows, out-flows and migration balances of Italian citizens, 1995-2014.

destinations among the countries offering a strong appeal for migrants (e.g. Germany, the United Kingdom and Sweden). In total, 323,000 Italians have moved to one of the eight selected countries, meaning that more than two out of three moves involving Italians within the EU are directed to one of the eight countries examined in this study.

In the same period, young Italians (aged 15-34 years) who left Italy and moved to an EU member country number more than 210,000 ( $44 \%$ of the total) and, of these, about $125,000(45 \%)$ chose a destination country with a strong tradition of drawing immigrants. The eight selected countries account for approximately 147,000 moves abroad by young Italians, or almost 70 percent of all moves by Italian young people within the EU (Table 1).

However, we should not forget that the data analyzed in this paper represent, as mentioned, an underestimation of international migration. For example, looking at Germany alone - which, like Italy, has local population registers, - it can be seen that the Federal Statistical Office of Germany counts more than 60,000 Italian citizens in the German population registers in 2013 (Statistisches Bundesamt 2015). It is true that, given the presence of Italian citizens in other European countries and on other continents, we cannot rule out the possibility of arrivals in Germany from other countries, but even so it appears that the data on cancellations of residence provided by the Italian registers is far too small (about 12,000 persons in 2013) because of citizens who fail to give official notification of their departure from Italy.

The distribution by marital status of flows of Italians abroad shows an ever-increasing proportion of unmarried persons (from 53\% in $1995-1999$ to almost $61 \%$ in $2010-2013$ ) with much higher values for unmarried individuals in the youngest age group, as high as 81 percent in the 2010-2013 period (Table 2). ${ }^{4}$

${ }^{4}$ With reference to the comparison with the total resident population in the examined period, it should be observed that the share of married people represent about 52 percent whereas singles are about 42 percent. The gender ratio is equal to 93.8 percent and the average age is about 41 years for men and 44 for women. 


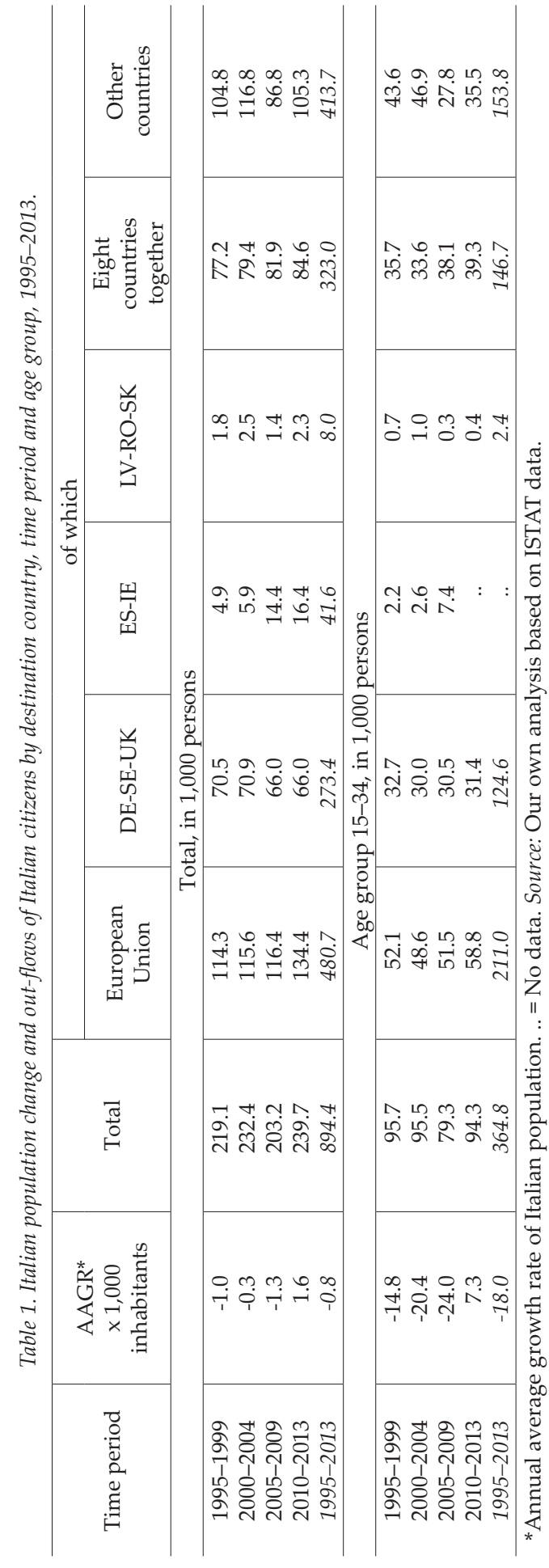

In the period from 1995 to 2013 , the gender ratio of people who moved abroad shows a meaningful trend toward balancing out. Although the gender ratio of Italians abroad continues to show a higher number of males, it registered a sharp decrease compared to the first half of the 1990s, especially for the 15-34 age group (the gender ratio dropped from nearly 152 males per 100 women in 1995-1999 to just over 127\% in 2010-2013).

The average age recorded, on the other hand, is growing, for both males and females. An increase of about 2 years has been seen from the beginning to the end of the period studied. For the youngest age group, the average increase is more moderate (about one year) but still shows a perceptible overall trend of increasing over the years (Table 2).

In addition, it should be considered that, with regard to young Italians moving, from 1995 to recent years there has been a change both in the age distribution of those moving and in the number whose destinations are among the 8 countries selected as opposed to other countries. Through 2004, the 15-24 age group shows, in relative terms, a higher incidence as compared with the total number of young people in the 15-34 group (Figure 2).

However, in later years a higher incidence is observed in the 25-34 age group. This changing trend can probably be related to the prevalence of mobility for work in more recent years compared to that for study typical of the first decade of the period considered.

\section{Regional aspects of places of origin and propensity to move to foreign countries}

Aspects of the issue of international mobility of Italians related to place of origin have always interested demographers, geographers, and, in general, population scholars, especially in recent years. However, since Italy underwent the transition from a labour exporting country to one that attracts immigrants, the focus on Italian emigration has in fact gradually waned. With the emergence of an economic crisis of major proportions, such as the 
Table 2. Out-flows of Italian citizens by time period, marital status, gender ratio, average age and age group, 1995-2013.

\begin{tabular}{|c|c|c|c|c|c|c|}
\hline \multirow{2}{*}{ Time period } & \multicolumn{2}{|c|}{ Marital status } & \multirow{2}{*}{ Gender ratio } & \multicolumn{3}{|c|}{ Average age } \\
\hline & single & married & & women & men & together \\
\hline \multicolumn{7}{|c|}{ Total, in $\%$} \\
\hline 1995-1999 & 53.1 & 44.2 & 143.2 & 31.8 & 32.8 & 32.4 \\
\hline 2000-2004 & 55.9 & 41.1 & 134.3 & 34.6 & 34.7 & 34.7 \\
\hline 2005-2009 & 57.5 & 37.6 & 132.2 & 35.1 & 35.9 & 35.6 \\
\hline 2010-2013 & 60.6 & 35.2 & 135.9 & 33.2 & 34.9 & 34.2 \\
\hline 1995-2013 & 56.8 & 39.5 & 136.4 & 33.7 & 34.6 & 34.2 \\
\hline \multicolumn{7}{|c|}{ Age group $15-34$, in $\%$} \\
\hline 1995-1999 & 64.3 & 34.7 & 151.6 & 26.4 & 26.3 & 26.3 \\
\hline 2000-2004 & 71.0 & 28.6 & 137.1 & 26.8 & 26.8 & 26.8 \\
\hline 2005-2009 & 77.1 & 22.2 & 126.9 & 27.4 & 27.7 & 27.6 \\
\hline 2010-2013 & 80.8 & 18.8 & 127.4 & 27.5 & 27.8 & 27.7 \\
\hline 1995-2013 & 73.1 & 26.3 & 135.8 & 27.0 & 27.1 & 27.1 \\
\hline
\end{tabular}

Source: Our own analysis based on ISTAT data.

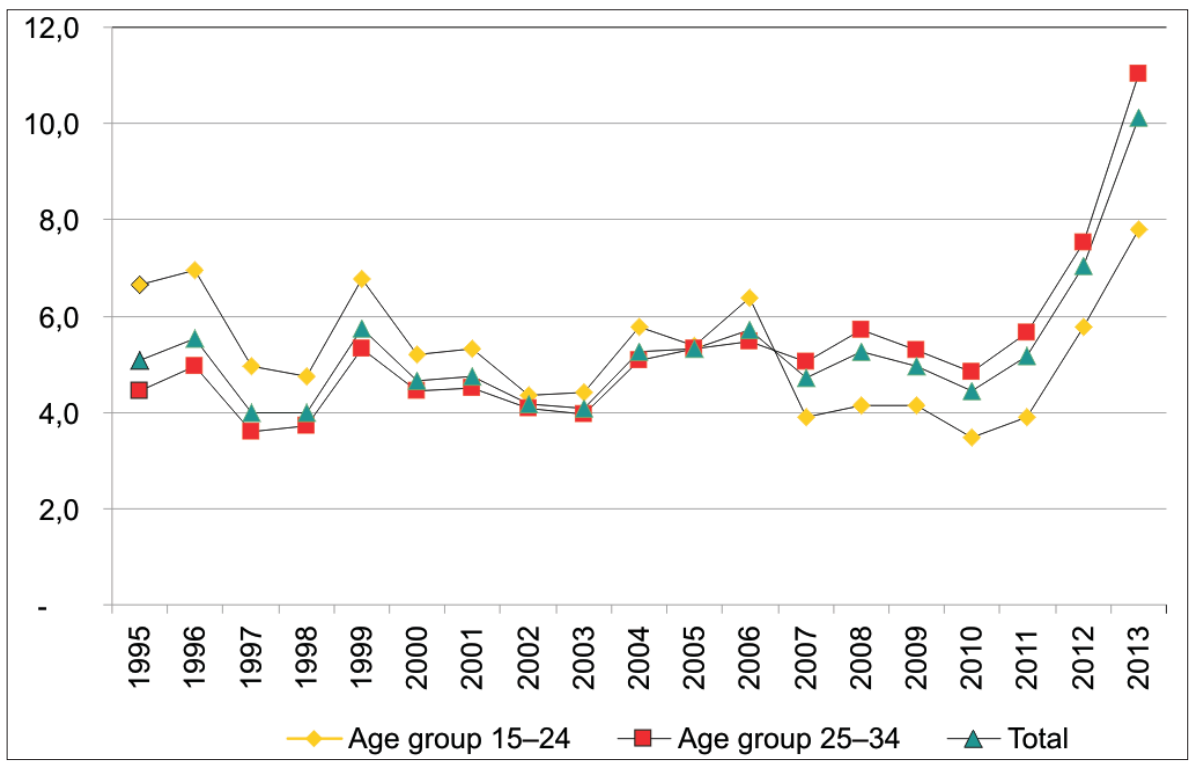

Fig. 2. Out-flows of young Italian citizens (aged 15-24 and 25-34) towards 8 selected countries (Germany, Ireland, Latvia, Romania, Slovakia, Spain, Sweden and the UK, 1995-2013). Source: Our own analysis based on ISTAT data

one that struck Europe at the end of the first decade of 2000, Italian emigration seems to have taken off again, arousing a new wave of great interest from the scientific community.

Compared to the past, however, the ambits in which Italians are moving internationally have changed considerably. In particular, the well-known processes typical of economic globalization and the markets that inevitably involve all areas of the planet, to the process of European integration which, until only a few months ago, seemed to have removed the last political and regulatory obstacles to the free movement of persons. To this we must also add the succession of new forms of communication and new communication tools, such as social networks, which can facilitate, at least at the beginning, processes of mobility within the EU. In this new framework, the regional differences and the dif- 
ferences in economic development that have, for decades, characterised Italy can change the intensity and characteristics of the current trends of Italians moving abroad.

Therefore, with regard to the youngest people of the Italian population, it seems appropriate to analyse which geographical areas of the country, in the course of the last decade, have been most affected by this new emigration trend, in order to identify the differences or similarities to places that traditionally fed such movement in the past (Table 3).

From 2002 to 2013, more than 227,000 young Italians moved abroad. In absolute terms, the geographical area that registered the highest number of expatriates was the north-west (over 56,000 individuals), followed by the south (almost 54,000), the north-east (more than 46,000 emigrants) and, finally, the centre and the islands (about 36,000 persons from each of the two geographical areas).

However, from 2002 to 2013 the northern and the central regions recorded a steady and continuous increase in the number of Italians moving abroad; for the last three-year period, the number of expatriates from these two areas doubled compared to the first two threeyear periods of the millennium. On the other hand, for the south and the islands, the values recorded are certainly significant, but still seem to be in line with the flows recorded during the first two three-year periods (Table 3).

Table 3. Out-flows of 15-34 years old Italian citizens to eight selected host countries by geographical origin, 2002-2013.

\begin{tabular}{|c|c|c|c|c|c|c|}
\hline \multirow{2}{*}{$\begin{array}{c}\text { Time } \\
\text { period }\end{array}$} & \multicolumn{5}{|c|}{ Geographical origin } & \multirow{2}{*}{ Italy } \\
\hline & North-West & North-East & Centre & South & Islands & \\
\hline \multicolumn{7}{|c|}{ Total, in persons } \\
\hline $2002-2004$ & 9,590 & 7,563 & 7,128 & 17,345 & 11,881 & 53,507 \\
\hline 2005-2007 & 10,311 & 9,140 & 7,848 & 11,804 & 8,512 & 47,615 \\
\hline 2008-2010 & 13,193 & 11,061 & 7,994 & 8,784 & 6,092 & 47,124 \\
\hline 2011-2013 & 23,141 & 16,848 & 12,834 & 15,905 & 10,191 & 78,919 \\
\hline 2002-2013 & 56,235 & 44,612 & 35,804 & 53,838 & 36,676 & 227,165 \\
\hline \multicolumn{7}{|c|}{ of which DE-SE-UK } \\
\hline 2002-2004 & 2,682 & 2,140 & 2,028 & 6,233 & 4,420 & 17,503 \\
\hline 2005-2007 & 2,890 & 3,119 & 2,382 & 5,662 & 4,979 & 19,032 \\
\hline 2008-2010 & 3,702 & 3,630 & 2,410 & 3,482 & 3,078 & 16,302 \\
\hline 2011-2013 & 6,278 & 5,130 & 3,827 & 6,165 & 5,109 & 26,509 \\
\hline 2002-2013 & 15,552 & 14,019 & 10,647 & 21,542 & 17,586 & 79,346 \\
\hline \multicolumn{7}{|c|}{ ES-IE } \\
\hline $2002-2004$ & 454 & 326 & 299 & 406 & 335 & 1,820 \\
\hline 2005-2007 & 1,196 & 920 & 890 & 486 & 438 & 3,930 \\
\hline 2008-2010 & 1,612 & 1,202 & 1,042 & 621 & 548 & 5,025 \\
\hline 2011-2013 & 1,732 & 1,182 & 1,168 & 1,051 & 672 & 5,805 \\
\hline 2002-2013 & 4,994 & 3,630 & 3,399 & 2,564 & 1,993 & 16,580 \\
\hline \multicolumn{7}{|c|}{ LV-RO-SK } \\
\hline 2002-2004 & 80 & 84 & 81 & 148 & 126 & 519 \\
\hline 2005-2007 & 45 & 59 & 39 & 21 & 18 & 182 \\
\hline 2008-2010 & 38 & 67 & 36 & 28 & 19 & 188 \\
\hline 2011-2013 & 101 & 104 & 72 & 83 & 37 & 397 \\
\hline 2002-2013 & 264 & 314 & 228 & 280 & 200 & 1,286 \\
\hline \multicolumn{7}{|c|}{ Eight countries together } \\
\hline $2002-2004$ & 3,216 & 2,550 & 2,408 & 6,787 & 4,881 & 19,842 \\
\hline 2005-2007 & 4,131 & 4,098 & 3,311 & 6,169 & 5,435 & 23,144 \\
\hline 2008-2010 & 5,352 & 4,899 & 3,488 & 4,131 & 3,645 & 21,515 \\
\hline 2011-2013 & 8,111 & 6,416 & 5,067 & 7,299 & 5,818 & 32,711 \\
\hline 2002-2013 & 20,810 & 17,963 & 14,274 & 24,386 & 19,779 & 97,212 \\
\hline
\end{tabular}

Source: Our own analysis based on ISTAT data. 

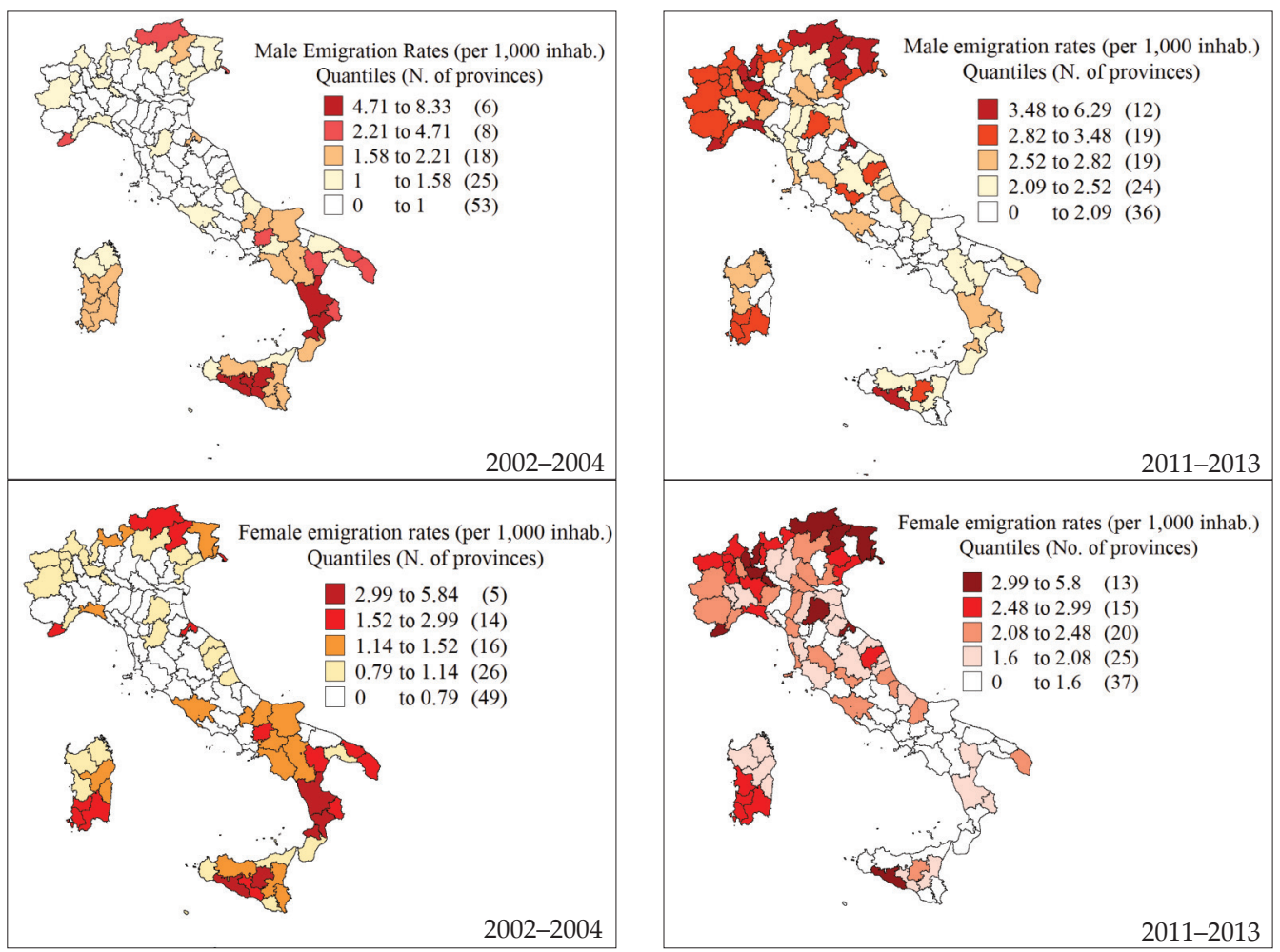

Fig. 3. Emigration rates of young Italians (aged 15-34), by province of origin and gender.

Source: Our own analysis based on ISTAT data.

According to official Italian statistics, during the 2002-2013 period, just under 100,000 Italians moved to one of the eight countries examined, and almost 80,000 of these chose destination countries with a strong tradition of attracting immigrants (e.g. Germany, the UK and Sweden).

Looking at the emigration rates by province, which have also been calculated by gender, we can analyse the propensity of Italian young people, male and female, to emigrate. Comparing the first three-year period (20022004) with the last one (2011-2013), very significant differences emerge in the propensity to emigrate from provinces in Italy.

In the first years of the $21^{\text {st }}$ century, the highest values for average emigration rates (ranging from 3 to 8 per thousand), for both males and females, are found in certain provinces of the South, especially in Calabria
(Cosenza, Catanzaro and Vibo Valentia) and Sicily (Enna, Caltanissetta and Agrigento). In the north, on the other hand, it is especially certain areas along the border in the provinces of Imperia, Bolzano, Pordenone and Trieste that show moderately intense emigration rates (between 2.0 and 4.7 per thousand), which moreover should be considered in terms of short-range moves across the border (Figure 3, a-b).

The situation, however, seems to completely reverse itself in the 2011-2013 emigration rates. This time it is mainly the provinces in the north-east, the north-west and the centre that show a greater propensity on the part of young people to emigrate, with higher levels (between 3.5 and 6.3 per thousand) among males in some northern provinces. Overall, the average intensity of emigration shows slightly lower values than those recorded 
in the first three years of the 2000s, but the phenomenon is by far more geographically widespread. Now emigration by young people is also seen in provinces that have been a driving force for the country's economy, including some in the Triveneto (Belluno, Treviso and Udine) and even the province of Bologna, which, for women specifically, shows very high emigration rates. Of the provinces in the north-west, we can point out Lecco, Como and Cremona, where the effects of the crisis in recent years have evidently been strongly felt in the textile manufacturing sector (Figure 3, c and d).

Among the provinces in the central region, those whose average emigration rates are significant, include certain provinces in Tuscany, Umbria and Marche and the province of Rome, while in the South the average rate of moves abroad involves more men from the provinces of Calabria and Apulia, and this is even more true with the provinces in Sardinia and some in Sicily (e. g. Agrigento and Enna).

It is interesting, though, that the propensity of young Italians to emigrate to one of the eight observed countries during the 20112013 period was even more widespread than the earlier measured average levels for young expatriates to all destinations (Figure 4).

This means that young Italians, from provinces in the north, south and the islands, show a greater propensity to migrate to the other eight EU countries than to other possible destinations. This trend is even more pronounced for young men, for whom migration rates are very significant in the southern provinces on the Adriatic side (e. g. Chieti, Campobasso, Foggia, Brindisi), and in the provinces of Basilicata and Calabria (Figure 4, $\mathrm{b}$ and $\mathrm{d}$ ).

Campania, and in particular its provinces Salerno, Avellino and Benevento, seem to be unique in the south, in that, despite traditionally being areas marked by emigration, they do not show significant levels of young Italians moving abroad during this most recent period. This situation, which is also widespread in other southern provinces, does corroborate alternative hypotheses regarding the "new state of need" which, according to some authors, has emerged among young people as a result of the recent economic crisis.

Over the last year, ISTAT has conducted an experiment using administrative data from multiple sources to define operational criteria for identifying the usual residence of individuals in Italy, according to the definitions of usually resident population adopted by the European regulations cited above. Based on these criteria, the data for persons recorded in the population register were matched with individual data from all administrative sources available to the institute, using a unique code to identify each individual. Data were consulted from the archives on employment (including contracts for collaboration, employee work and temporary work) and self-employment, the archive of students enrolled in schools and universities, pensioners records, tax statements (including with dependent family members), non-pension benefits and the archives for residence permits and for domestic work.

To identify the place of usual residence, the date 31 December 2013 was used, and indications of the individual's presence in or absence from Italy in the 12 months before and the 12 months following that date were considered. This criterion made it possible to identify the following critical subpopulations: persons usually resident in Italy but not recorded in the municipal register; and individuals who are registered but for whom the administrative sources cited above nonetheless contain no indications. This second group of individuals, in the 15-34 age group, includes about 500,000 Italians who are largely representative of the so-called "NEET generation" (not engaged in education, employment or training). This subpopulation without administrative indications other than in population registers is, in terms of geographical distribution, strongly concentrated in the central and southern provinces (Figure 5), or in other words, in areas where long-term unemployment and the loss of jobs generated by the crisis that began in 2007-2008 have been most substantial. 

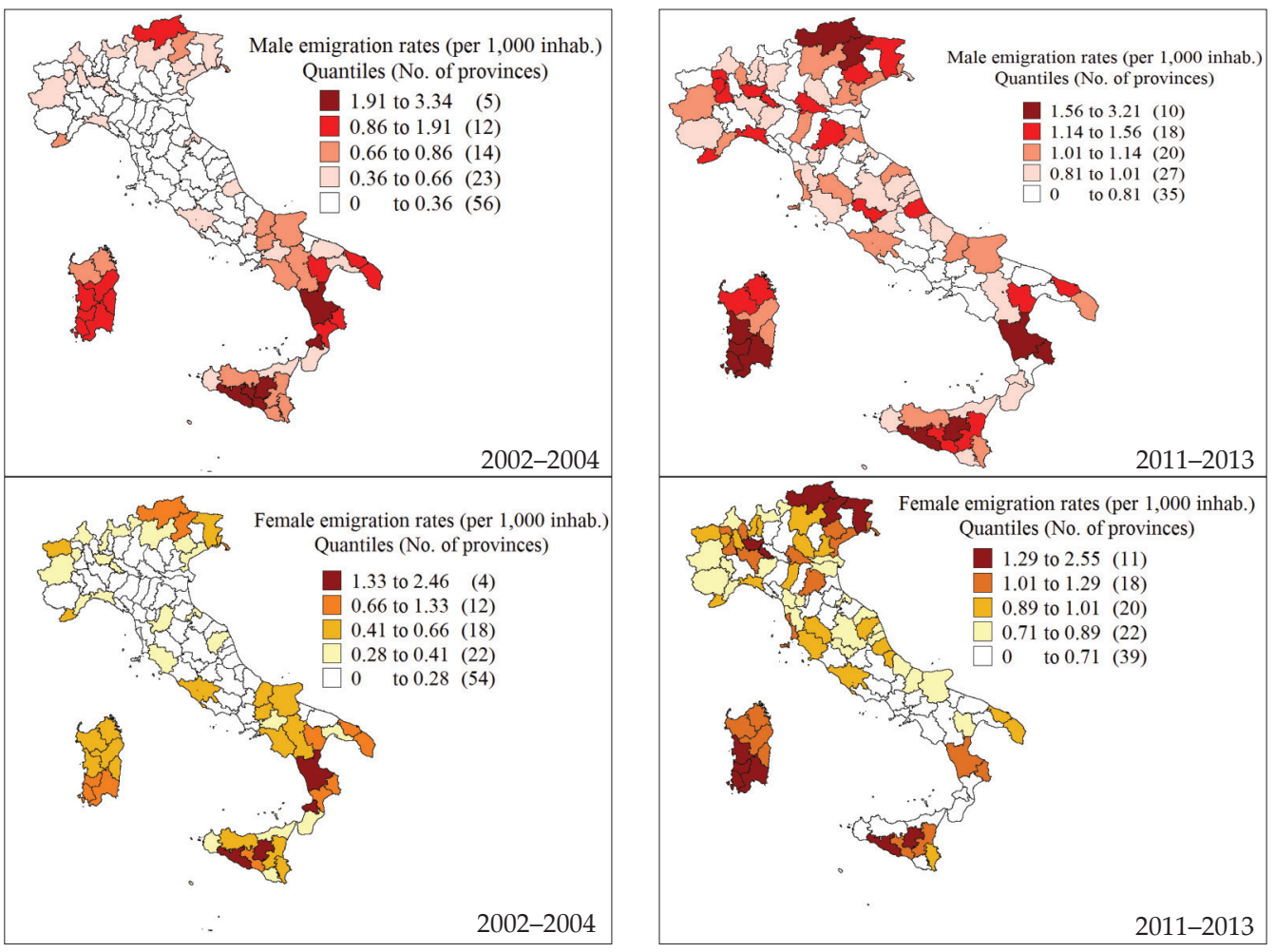

Fig. 4. Emigration rates of young Italians (aged 15-34) to 8 selected countries (Germany, Ireland, Latvia, Romania, Slovakia, Spain, Sweden and the UK), by province of origin and gender. Source: Our own analysis based on ISTAT data
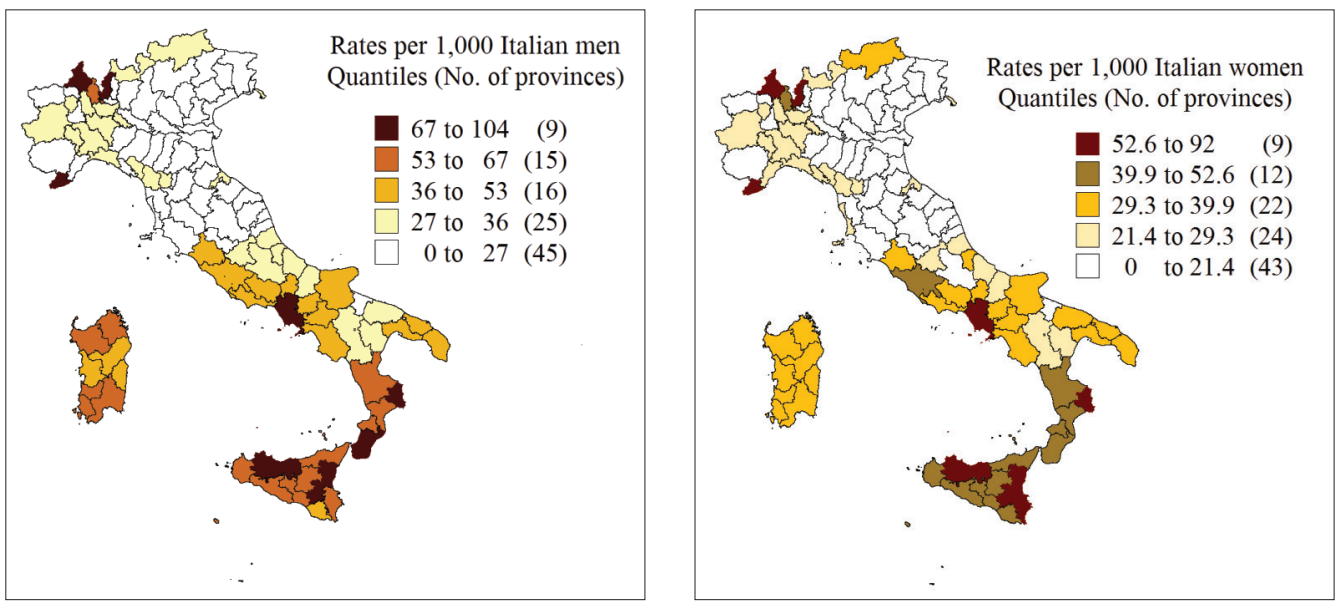

Fig. 5. Young Italian citizens (aged 15-34) recorded in municipal population registers, "without indications" in other administrative sources, 2012-2014. Source: Our own analysis based on ISTAT data. 
The thematic map shows that these young Italians are highly concentrated in the provinces of Lazio, Campania, Sicily and Calabria: particularly, the provinces of Rome, Naples, Palermo and Crotone. Some moderately high numbers of persons with Italian citizenship are also found in some provinces in the north along the borders with Switzerland, France and Austria, but these must be considered predominantly in relation to the phenomenon of frontier workers. The major concentration of young people in the southern provinces who are not part of the labour market should, as a result of the still-ongoing economic crisis, feed major migratory flows toward foreign countries.

However, we have seen that the emigration rates are higher in the northern provinces and do not entirely overlap the spatial distribution of social disease of young Italian who usually reside in the provinces of the centre and the south and who are characterized by an higher absence of indications of study and work in administrative sources other than the population registers. This suggests that the recent international migration of Italians is not entirely due to the situation of need that supposedly emerged from the recent economic crisis to which most of the national and international scientific literature refers to.

\section{Discussion and conclusions}

Analysis by area of origin at the provincial level has demonstrated that it has not been only the traditionally underdeveloped areas - those in the south of Italy - to see an increase in out-migration, but also regions that were prosperous until a few years ago, such as those of the north-east and some border areas in the Alps. The reason might perhaps be found in the Italian industrial system crisis that has hit several areas of the country. In the north-east, the crisis involved mainly small and medium-sized enterprises, which initially reacted by moving operations to areas of Europe with lower labour costs (Eastern Europe) and later by shutting down com- pletely. The south, by contrast, has always been one of Italy's least developed areas.

However, the crisis aggravated the situation; between 2007 and 2013, the real GDP fell by about 14 percent and there was a drop in spending, even on food, in both public and private investments and in net capital stock. Meanwhile, there was an increase in the unemployment rate for young people. In the 15-34 age group, the unemployment rate in the south in 2014 was 23.9 percent (SVIMEZ 2015) and in December 2015 the unemployment rate for the very young people (aged 15-24) was 37.9 percent (EUROSTAT 2016b). Thus, the instability of the labour market increased in the South, but also in Italy in general, and this seems to be one of the main factors that push young people abroad.

This "instability" is the result of the fact that the principles of "flexicurity" being borrowed from the countries of Northern Europe and applied in the Mediterranean countries. However, when transferred to a less-developed welfare system slow to adapt to new job profiles because of the new employment contracts used, in order to lower labour costs, these resulted in instability instead of flexibility (RAfFini, L. 2014). Therefore, in Italy and in other Mediterranean countries, there is a generation of young people caught in the "trap" of job insecurity (Murgia, A. 2010), a generation living their lives in a series of unstable or temporary jobs that do not allow them to plan secure futures.

As regards the United Kingdom, in recent decades, emigrants moving to London from Italy were primarily young people going to study in prestigious universities or highly qualified workers going to work in banks, finance companies and hedge funds, insurance companies, legal companies and universities; these were the Eurostars described by FAVELL, A. (2008). Today in London, however, there are also young Italians who cannot find opportunities in Italy. Finding employment in London is easy, but contracts are often temporary or part-time, the work is strenuous and wages are relatively low. The minimum wage for people over the age of 22 is $£ 6.50$. 
They are working in low-level jobs: bartenders, waiters, chefs, deliverymen, dishwashers, receptionists and bellboys (McKAY, S. 2015).

Young Italians moving to Germany today have a higher level of education than those of past decades and, above all, good social and personal relationships and an excellent level of integration. Despite their qualifications and degrees, they are working in lowskilled jobs - services, especially in food service and customer care - often intermittent or temporary, alternating periods of work and periods of unemployment, periods in Germany and periods in Italy or in other countries (QuADrelli, F. 2014).

But if the labour situation abroad in the most attractive countries is so difficult, why do Italian youth want to relocate? Part of the answer can be found in some recent studies on Italian graduates (KING, R. and Conti, F. 2013; KInG, R. et al. 2014, 2016b) that point out how young Italians are fleeing from something intangible as well as from economic stresses and employment crisis. They are running away from a system they call "gerontocratic", "clientelist", "corrupt" and "not merit-based", where finding a job requires "recommendations" and networks of personal connections. There is also a flight from the "Italian mentality" which is defined as "provincial" and "narrow-minded".

It is important to observe how the social composition of the young Italians who move abroad has changed. Young Italians - and young people from Mediterranean Europe in general who move to Northern European countries - are born Europeans, with a sense of European identity and previous experience abroad from their time as students (the Erasmus Generation); treat the EU as the larger space in which they see their futures. These young people experience Europe as an open space and a single labour market within which one can move freely. Therefore, they see themselves as mobile citizens, not as migrants, and they see their future as open - open to the stability of their destination country, open to returning to their country of origin, open to moving to new destina- tions (RAFrini, L. 2014; Zurla, P. 2014). At the same time, however, it should be noted that for Mediterranean young people there is a very fine line between being "compelled" to move and "desiring" to move. RAFFINI, L. (2014) points out that, on the one hand, highly qualified young people, once they move, have the opportunity to work in stimulating and cosmopolitan environments and to develop transnational relationships but, on the other hand, they experience a sense of instability and uncertainty about future work and building a family.

In interpreting the phenomenon of the mobility of Italian young people, we must bear in mind the trends, but also the absolute values. In terms of the latter, even we wonder, following Livi BACCI, M. (2014), if indeed, we can speak of a real brain drain. Livi BACCI notes that, according to the most recent surveys, the international mobility of doctoral students is rather low $(6.4 \%$ of Italians who earned PhDs in 2004 and 2007 were living abroad at a point five years or three years after having completed the degree) and mobility among university graduates is even lower (one year after earning a graduate degree, $4 \%$ were working abroad). A closer look reveals, furthermore, that PhDs and university graduates belong to the privileged classes of Italian society and that those who move abroad come from the families with the highest incomes and education levels; the experience of mobility is for those who do not have a concrete need. In addition, in 2014, for the first time since 2008 the percentage of graduates returning from abroad ( $34.7 \%$ of the total) was higher than the percentage of university graduates who moved abroad (30\% of the total) (ISTAT 2015). We will have to wait for final data for 2015 to check whether the trend has reversed itself or whether this was an isolated case.

In this paper we've shown that an increase in the international youth migration of Italians took place after the financial and economic crisis started. Data have shown that new areas of origin have emerged in the recent years and that the Mezzogiorno 
(south) cannot be considered a homogeneous unit but should be considered as a composite and complex system - not one Mezzogiorno (south), then, but multiple Mezzogiorni (south(s). Our analysis has also shown that several factors contribute to youth mobility and that the economic factors may not always be the most important ones. Further researches at a finer spatial scale, including qualitative analysis, will be necessary to deepen our conclusions.

Acknowledgements: The research leading to these results received funding from the Horizon 2020 YMOBILITY project (Youth Mobility: Maximising Opportunities for Individuals, Labour Markets and Regions in Europe), grant agreement no. 649491. Project website: www.ymobility.eu.

\section{REFERENCES}

Alba-Monteserín, S., Fernández-Asperilla, A. and Martínez-Veiga, U. 2013. Crisis económica y nuevo panorama migratorio en España. Colección Estudios - Fundación Primero de Mayo 65. http://www.1mayo. ccoo.es/nova/files/1018/Estudio65.pdf.

Bonifazi, C. 2015. Le migrazioni tra Sud e CentroNord: persistenze e novità. In La nuova migrazione italiana. Cause, mete e figure sociali. Ed.: GJERGJI, I., Venezia, Edizioni Ca' Foscari, 57-69.

Chieppa, A., Gallo, G., Tomeo, V., Borrelli, F. and Di Domenico, S. 2016. Knowledge Discovery process to Derive Usually Resident Population from Administrative Registers. Paper presented to Conference on Data Science \& Social Research. Naples, February 17-19. 2016.

Cibella, N., Gallo, G., Pezone, A. and Tuoto, T. 2015. The integration between the 2011 Census Post Enumeration Survey Data and Administrative Data. The Analysis on Hard-to-Count Population. Paper presented to the Population Days Conference. Palermo, February 4-6. 2015. http://docplayer. it/7999402-conference-program-and-abstracts.html.

Díaz-Hernández, R., Domínguez-Mujica, J. and Parreño-Castellano, J. 2015. Una aproximación a la emigración española durante la crisis económica: herramientas de estudio.Ar@cne. Revista electrónica de recursos en Internet sobre Geografía y Ciencias Sociales 198. http://www.ub.es/geocrit/aracne/ aracne-198.pdf.

Domingo, A., Sabater, A. and Ortega, E. 2014. Migración neohispánica? El impacto de la crisis económica en la emigración española. Empiria. Revista de Metodología de las Ciencias Sociales 29.39-66.
Domínguez-Mujica, J. and Pérez-García, T. 2016. The economic crisis and the Southern European migration model. A comparative analysis. In European Mobility in Times of Crisis. The new context of European South-North Migration. Eds.: GLorius, B. and Domínguez-Mujica, J. Bielefeld, TranscriptVerlag. (Forthcoming)

EUROSTAT 2016a. Fertility statistics. Retrieved September 20, 2016, from http://ec.europa.eu/eurostat/statistics-explained/index.php/Fertility_statistics

EUROSTAT 2016b. Unemployment statistics. Retrieved February 12, 2016, from http://ec.europa. eu/ eurostat/statistics-explained/index.php/ Unemployment_statistics.

FAvelL, A. 2008. Eurostars and Eurocities: Free Movement and Mobility in an Integrating Europe. Oxford, Blackwell.

Giannola, A. 2015. Crisi del Mezzogiorno e nuove spinte migratorie. In La nuova migrazione italiana. Cause, mete e figure sociali. Ed.: GJERGJI, I., Venezia, Edizioni Ca' Foscari, 39-56.

HAUG, S. 2015. New migration from Italy to Germany. Chain migration or circular migration? In La nuova migrazione italiana. Cause, mete e figure sociali. Ed.: GJergjı, I., Venezia, Edizioni Ca' Foscari, 83-110. https://comparativemigrationstudies.springeropen. com/articles/10.1186/s40878-016-0023-1

ISTAT 2015. Migrazioni internazionali e interne della popolazione residente. Anno 2014. Rome, ISTAT.

Jouen, M. 2014. The single market and cohesion policy dyad: battered by the crisis and globalization. Notre Europe, Policy Paper 108.

KING, R. and ContI, F. 2013. Bridging the divide: the gap between the study of internal and international migration, with an Italian example. Willy Brandt Series of Working Papers in International Migration and Ethnic Relations 1. Malmö, University of Malmö.

King, R., Lulle, A., Conti, F. and Mueller, D. 2016 b. Eurocity London: a qualitative comparison of graduate migration from Germany, Italy and Latvia. Comparative Migration Studies 4. (3).

King, R., Lulle, A., Conti, F., Mueller, D. and Scotto, G. 2014. The lure of London: a comparative study of recent graduate migration from Germany, Italy and Latvia. Working paper 75, Sussex, Sussex Centre for Migration Research-University of Sussex.

King, R., Lulle, A., Morosanu, L. and Williams, A.M. 2016a. International youth mobility and life transitions in Europe: questions, definitions, typologies and theoretical approaches. Working paper 86. Sussex, Sussex Centre for Migration Research-University of Sussex.

Labrianidis, L. and Vogiatzis, N. 2013. The mutually reinforcing relation between international migration of highly educated labour force and economic crisis: the case of Greece. Southeast European and Black Sea Studies 13. (4): 525-521.

Lrvi BAcci, M. 2014. "Fuga dei cervelli": o non c'è o non si vede per ora. IN Le migrazioni internazionali 
ai tempi della crisi. Ed.: Bonifazi, C. and Livi BaCCI, M., Roma, Associazione Neodemos, 104-108. http:// www.neodemos.info/doc/E-book_bonifazi.pdf.

Livi BACCI, M. 2016. Brexit: la demografia, purtroppo, c'entra! Neodemos, 1-4. http://www.neodemos.info / brexit-la-demografia-purtroppo-centra/?print=pdf.

Lowell, B.L. and Findlay, A. 2002. Migration of Highly Skilled Persons from Developing Countries: Impact and Policy Responses. Geneva, International Labour Office. McKay, S. 2015. Young Italians in London and in the UK. In La nuova migrazione italiana. Cause, mete e figure sociali. Ed.: GJergu, I., Venezia, Edizioni Ca' Foscari, 71-82.

McKay, S. 2015. Young Italians in London and in the UK. In La nuova migrazione italiana. Cause, mete e figure sociali. Ed.: GJERGJI, I., Venezia, Edizioni Ca' Foscari, 71-82.

Murgia, A. 2010. Dalla precarietà lavorativa alla precarietà sociale. Biografie in transito tra lavoro e non lavoro. Bologna, Emil di Odoya.

PIChler, E. 2015. Italiani in Germania a 60 anni dagli accordi bilaterali: Trasformazioni delle Comunità e partecipazione. Neodemos, 1-3. http://www. neodemos.info/italiani-in-germania-a-60-dagliaccordibi laterali -trasformazioni-della-comunitae-partecipazione/?print=pdf.

Poulain, M. and Herm, A. 2013. Le registre de population centralisé, source de statistiques démographiques en Europe. Population 68. (2): 215-247.

Pugliese, E. 2015. Le nuove migrazioni italiane: il contesto e i protagonisti. In La nuova migrazione italiana. Cause, mete e figure sociali. Ed.: GJERGJI, I., Venezia, Edizioni Ca' Foscari, 25-38.

Pumares, P. 2015. Cosas que hacer en Brighton mientras escampa la crisis. El atractivo de Brighton para los jóvenes españoles en tiempos de crisis. In Libro de resúmenes de ponencias y comunicaciones al VIII Congreso sobre las Migraciones Internacionales en España. Eds.: García Castaño, FJ., Megías, A. and OrtegA, J., Granada, Instituto de Migraciones, Universidad de Granada, 305-306.
QuAdrelli, F. 2014. Una nuova fase per l'emigrazione italiana? In Le migrazioni internazionali ai tempi della crisi. Eds.: Bonifazi, C. and Livi Bacci, M., Neodemos. 100-103. http://www.neodemos.info/doc /E-book_bonifazi.pdf.

RAFFINI, L. 2014. Quando la generazione Erasmus incontra la generazione precaria. La mobilità internazionale dei giovani italiani e spagnoli. OBETS. Revista de ciencias sociales 9. (1): 139-165.

Sassen, S. 2001. The Global City: New York, London, Tokyo. Princeton, Princeton, University Press, Princeton.

Statistisches Bundesamt 2015. Migration $\mathcal{E}$ Integration. https://www.destatis.de/DE/ ZahlenFakten /GesellschaftStaat/Bevoelkerung/ MigrationIntegration/MigrationIntegration.html; jsessionid=20154DE2EA0C8A3371ECAE5EA3876 79A313F.cae1.

SVIMEZ 2015. Rapporto SVIMEZ 2015 sull'economia del Mezzogiorno. Bologna, Il Mulino.

Triandafyllidou, A. and Gropas, R. 2014. 'Voting with their feet': highly skilled emigrants from Southern Europe. American Behavioral Scientist 58. (12): 1614-1633.

UNECE 1998. Recommendations on statistics of international migration. Statistical Papers, Series M. 58. Rev. 1. New York, Department of Economic and Social Affairs, Statistics Division, UN.

Wallgren, A. and Wallgren, B. 2011. To understand the Possibilities of Administrative Data you must change your Statistical Paradigm! Proceedings of the Survey Research Methods Section. American Statistical Association, Invited Paper.

ZurLA, P. 2014. L'emigrazione dei giovani italiani alla ricerca di lavoro: mobilità o fuga dei cervelli. Sociologia del Lavoro 136. 51-70. 